\title{
HODNOCENÍ PRORODINNÉ ATMOSFÉRY MEZI MLADÝMI VĚŘÍCÍMI ${ }^{1}$
}

\author{
Hana Wisetková, Marek Kolařik
}

\begin{abstract}
Abstrakt
Článek pojednává o kvantitativní studii zaměřené na zmapování hodnocení prorodinné atmosféry v církevním prostředí mezi mladými věrícími (od 17 do 30 let). Teoretické zázemí se opírá o uchopení pojmu prorodinná atmosféra, právní zakotvení církví v České republice se zaměřením na popis Ř́mskokatolické církve a Slezské církve evangelické a.v., vývoj hodnoty manželství a rodiny v církevní i sekulární společnosti a křest’anské pojetí manželství, rodiny a předmanželských vztahů, včetně jejich souvisejících aspektů. Empirická část vychází $\mathrm{z}$ anonymního šetření prostřednictvím online dotazníku se zaměřením na sociodemografické a náboženské charakteristiky, hodnotový žebříček (zjištován standardizovanou Rokeachovou škálou hodnot) a hodnocení položek týkajících se prorodinné atmosféry v církvi, partnerských a manželských vztahů a sexuality. Výzkumu se zúčastnilo 262 respondentů. Získaná data byla zpracována popisnou statistikou, parametrickými a neparametrickými testy. Výsledky poukazují na odlišnou preferenci hodnot mezi věřícími v souvislosti $\mathrm{s}$ jejich rodinným stavem, který rovněž má vztah $\mathrm{k}$ míře spokojenosti s prorodinnou atmosférou. Dále byl prokázán vztah náboženské praxe a shody vlastních názorů s křest’anskými stanovisky. V závěru je pojednáno o limitech práce a př́ípadných intervencích či podnětech pro další studie.

Klíčová slova: prorodinná atmosféra, církev, Rokeachova škála hodnot
\end{abstract}

\section{EVALUATION OF PROFAMILY ATMOSPHERE AMONG YOUNG BELIEVERS}

\begin{abstract}
The article discusses a quantitative study which maps the evaluation of pro-family atmosphere in a church among young believers (from 17 to 30 years). The theoretical background is based on understanding the concept of pro-family atmosphere, the legal base of churches in the Czech Republic with a focus on the Roman Catholic Church and the Silesian Evangelical Church description, the value development of marriage and family in church and secular society and the Christian concept of marriage, family and premarital relations, including their related aspects. The empirical part is based on anonymous surveys by an on-line questionnaire focusing on sociodemographic and religious characteristics, the scale of values (surveyed by the standardized Rokeach Value Survey) and the evaluation of questions about pro-family atmosphere in a church, partner and marriage relationships and sexuality. 262 respondents participated in the research. The obtained data were processed by descriptive statistics, parametric and nonparametric tests. The results indicate different value preferences among believers in relation to their marital status, which is also related to the degree of satisfaction with the pro-family atmosphere. The results confirmed the relation of religious practice and agreement between personal and Christian opinions. In conclusion, it discusses the limits of the research and possible interventions and suggestions for further study.
\end{abstract}

Key words: pro-family atmosphere, church, Rokeach Value Survey

Došlo do redakce: 16. 11. 2015

Schváleno k publikaci: 7. 4. 2018

\footnotetext{
${ }^{1}$ Článek vychází z diplomové práce: Kotasová H. (2015). Hodnoceni prorodinné atmosféry mezi mladými věrícími. Nepublikovaná diplomová práce. Olomouc: Univerzita Palackého.

Vedoucí: PhDr. Marek Kolařík, Ph.D.
} 


\section{Úvod}

Partnerské vztahy jsou českou populací stále vnímány jako jedna z nejdůležitějších hodnot (Čadová, 2014), nicméně př́stup k nim se liší mezi sekulární a církevní společností. Široká veřejnost nevnímá instituci manželství jako potřebnou, což se odráží v rozšiřování fenoménu nesezdaného soužití a ve snižování počtu uzavřených manželství (Sobotková, 2007; Fialová, 2006). V křest’anské společnosti je manželství považováno za přirozenou součást života jedince a založení rodiny je jedním z jeho základních úkolů, přičemž tyto koncepce mají své biblické kořeny (viz Gn 1:26-28 Český ekumenický překlad).

Křest'anské pojetí partnerských, manželských a rodinných vztahů se opírá jak o biblická stanoviska, tak o koncepce vycházející z jednotlivých církví. Základní uchopení nacházíme již ve Starém zákoně (viz Gn 1:26-28; Gn 2:18-24) - přestože se jedná o dvě rozdílné verze stvoření lidstva, je možné zachytit několik výchozích myšlenek týkajících se manželství: 1) člověku je vrozená potřeba být $s$ druhým člověkem v páru; 2) manželství je důležitým prvkem v duchovním životě jedince, nebot' slouží jako prostředek přiblížení se k Bohu; 3) manželství slouží k plození dětí; 4) manželstvím se dva lidé oddělují z původní rodiny a zakládají novou. Také další biblické knihy se vyjadřují k tématům partnerských vztahů, např. Píseň písní, evangelia, či dopisy apoštola Pavla jednotlivým církvím. Obvykle se jedná o texty vyjadřující se ke smyslu manželství (např. Ef 5:21-32, Mt 19:5-6), sexualitě (např. Píseň písní, 1K 7:3-5), postavení mužů a žen (např. Ef 5:21-32), prevenci před nevěrou (např. Žd 13:4, 1K 7:2-6) apod. Jednotlivé církve na tyto biblické myšlenky navazují ve vlastním učení, které je dále předáváno členům dané církve (např̀. Katechismus katolické církve, 1995; Jan Pavel II., 1996; Česká biskupská konference, 2001; Suchá et al, 2006; Zásady Slezské církve evangelické a. v., 2004; Adventisté sedmého dne věří, 1999 a další).

Význam manželství a rodiny se $\mathrm{v}$ průběhu církevní historie měnil. V biblických dobách bylo manželství prostředkem ke sjednocení rodu, který přežíval a rozšiřoval se díky potomstvu, které dále zvedalo i jeho prestiž. V období rané církve byla rodina jakýmsi modelem pro setkávání křest'anů. V průběhu dalších staletí, kdy docházelo mimo jiné k postupnému rozvolňování manželské morálky, rozšiřování nevěry a zvyšování počtu rozvodů, církev zaujala pozici zaměřenou na ochranu manželství, které je v návaznosti na Starý zákon považováno za hlavní prostředek k plození dětí a ochrany před sexuálním hříchem (Dolista, 1994; Bible, 2001) ${ }^{2}$.

I navzdory sekularizaci je hodnota manželství a rodiny v křest'anském prostředí v současné době vysoce postavena. Církev se v těchto otázkách snaží se svými členy efektivně pracovat, a to jak s jedinci svobodnými, zadanými, zasnoubenými i sezdanými. Zaměření církve na rodinné hodnoty potvrzují české i zahraniční výzkumy (Čadová, 2014; Eriksson, et al., 2013; Pedersen, 2014). Touto prorodinnou orientací církve vzniká mezi křest’any nálada úzce související s partnerskými vztahy. Lze hovořit o tzv. „prorodinné atmosféře“, která představuje souhrn teorií a postupů/programů, které podporují instituci manželství a rodiny ve společnosti a který následně zpětně ovlivňuje ovzduši uvnitř této společnosti.

\footnotetext{
${ }^{2} \mathrm{~V}$ této oblasti je nutné také zmínit koncepci celibátu, tedy zřeknutí se manželského svazku pro službu Bohu, což je trend, který se rozvíjí zejm. v období církevního středověku. Po tzv. Tridentském koncilu (1545 - 1563) se značná část křest’anské společnosti a církví od tohoto konceptu odklonila (Dolista, 1994).
} 


\section{Výzkumné cíle}

Hlavním výzkumným cílem bylo zmapování hodnocení prorodinné atmosféry v církevním prostředí mezi mladými věřícími. Zkoumány byly zejména hodnotové preference mladých křest’anů, souvislost náboženské praxe a vnímání vlastních, biblických a církevních názorů týkajících se partnerských vztahů a celkové hodnocení prorodinné atmosféry ve vztahu s rodinným stavem jedince.

\section{Výzkumný soubor}

Do výzkumného souboru byli samovýběrem zařazeni respondenti spadající do věkového rozmezí od 17 do 30 let, kteř́ jednoznačně uvedli, že jsou věřící. Výzkumu se tedy účastnilo celkem 262 jedinců (průměrný věk 22,5 let), z toho 77 mužů (průměrný věk 23,2 let) a 185 žen (průměrný věk 22,3 let). Nejvíce se účastníci hlásili k Římskokatolické církvi (38,5 \%), dále pak k Slezské církvi evangelické augsburského vyznání $(26,3 \%)^{3}$. Více než $1 / 4$ z celkového souboru chodí pravidelně nebo téměř pravidelně do kostela a na setkání mládeže, denně nebo skoro každý den čtou Bibli a modlí se. Zmapování rodinného stavu respondentů je uvedeno v tabulce č. 1 . Ze všech respondentů aktuálně v partnerském vztahu $(\mathrm{N}=114)$ jich 66,6 \% má svůj první nebo druhý vztah, dalších $27,5 \%$ respondentů svůj třetí nebo čtvrtý vztah a 5,3\% respondentů už mělo více než pět partnerů. Ze všech zadaných respondentů má 87,8 \% věřícího partnera.

Tabulka č. 1

Rodinný stav respondentů

\begin{tabular}{llllll}
\multirow{2}{*}{ Pohlaví } & \multicolumn{3}{c}{ Rodinný stav } & Celkem \\
\cline { 2 - 5 } & svobodní & zadaní & zasnoubení & sezdaní & 77 \\
\hline muži & 49 & 16 & 3 & 9 & 185 \\
ženy & 99 & 43 & 12 & 31 & 262
\end{tabular}

\section{Aplikovaná metodika a sběr dat}

Vzhledem k šíri výzkumu byla zvolena kvantitativní strategie, pro sběr dat byl použit online dotazník. Emanovský (2013) hodnotí šíření dotazníku prostřednictvím internetu jako velkou časovou a finanční úsporu a vyzdvihuje možnost zachycení velkého výzkumného souboru.

3 Dále se $10 \%$ respondentů hlásilo k Církvi bratrské, $8 \%$ respondentů k Apoštolské církvi, ke Křest’anskému společenství a kjiným evangelickým církvím po 2,7 \% respondentů, 2,3\% respondentů k Církvi adventistů sedmého dne, 1,9 \% respondentů k Jednotě bratrské, k Českobratrské církvi evangelické a $\mathrm{k}$ Církvi živého Boha po 1,5\% respondentů a $0,4 \%$ respondentů k Bratrské jednotě baptistů. Jinou církevní př́íslušnost uvedlo $0,4 \%$ respondentů a 3,4 \% respondentů svou církevní př́íslušnost neuvedlo. 
Použitý dotazník byl vlastní konstrukce a zaměřoval se cíleně na tyto oblasti ze života respondentů: sociodemografické charakteristiky, historie partnerských vztahů, náboženská praxe, hodnotový žebrríček, hodnocení prorodinné atmosféry v církvi, míra souhlasu s církevními a biblickými stanovisky, které se týkají partnerských a manželských vztahů a rodiny, včetně subjektivního názoru. Výzkumný nástroj představovala Likertova škála, která prostřednictvím vyjádření míry souhlasu/nesouhlasu s určitým výrokem umožňuje zachytit postoje a názory respondentů (Emanovský, 2013). Hodnotový žebříček účastníků byl zkoumán pomocí standardizované Rokeachovy škály hodnot (Rokeach Value Survey). Tuto škálu tvoří seznam 36 hodnot, které jsou rozděleny na hodnoty terminální (cíle a ideály jedince) a instrumentální (prostředky a způsoby chování, kterými daný jedinec dosahuje svých cílů a ideálů; Řehan, Cakirpaloglu, 2000).

\section{Analýza dat}

Vzhledem k povaze dat byla k jejich zpracování nejvíce využita popisná statistika. Skupiny respondentů byly dále porovnávány neparametrickými testy zjištujícími rozdíly (MannWhitneyho U test, Test dobré shody $\chi^{2}$ a Kruskal-Wallisova analýza rozptylu) ${ }^{4}$ a korelačními koeficienty pro posouzení stupně souvislosti mezi skupinami (Spearmanův a Pearsonův korelační koeficient; Šejda, Šmerhovský, Göpfertová, et al., 2005).

\section{Etické aspekty}

Spolu s dotazníkem obdrželi potenciální účastníci studie také motivační dopis, který obsahoval informace o účelu výzkumu, následném zpracování dat a možnostech využití výstupů. Účast ve výzkumu byla dobrovolná a v kterékoli fázi mohla být ukončena. Ochrana osobních a citlivých informací byla zajištěna anonymitou dotazníku.

\section{Výsledky studie}

Výsledky výzkumu jsou roztříděny do oblastí, na které byla studie cíleně zaměřena.

\section{Hodnotové preference mladých křest'anů}

Z oblasti preference hodnot je pro mladé křest’any nejvýznamnější terminální hodnotou Spása duše (Mdn pořadí hodnoty $=1$ ), a poté hodnoty týkající se partnerských a rodinných vztahů, konkrétně hodnoty Rodinné bezpeči a Zralá láska (obě Mdn = 3). Z instrumentálních hodnot se jeví jako nejdůležitější hodnoty Čistota, Poctivost (obě Mdn = 3) a Laskavost $(\mathrm{Mdn}=4)$.

\footnotetext{
${ }^{4}$ Mann-Whitneyho U test pracuje s pořadovými hodnotami pro určení, jestli skupiny respondentů pocházejí ze stejné populace. Test dobré shody $\chi 2$ umožňuje porovnání rozdělení sledovaného znaku ve skupinách výběrového souboru a pravděpodobnostní rozdělení daného znaku. Pomocí KruskalWallisovy analýzy rozptylu byly mezi sebou porovnávány skupiny respondentů (Šejda, Šmerhovský, Göpfertová, et al., 2005).
} 
Mezi nezadanými a zadanými jedinci existují rozdíly $\mathrm{v}$ preferenci hodnot uvedených $\mathrm{v}$ tabulce č. 2, přičemž tyto rozdíly byly statisticky potvrzeny na $5 \%$ hladině významnosti. Další rozdíl, z pohledu práce významný, se týká hodnot Moudrost a Krása. Nezadaní jedinci rovněž považují hodnotu Zralá láska za méně důležitou než zadaní, ale pozitivněji hodnotí Upřimné přátelství. Ve srovnání s běžnou populací (Řehan, Cakirploglu, 2000) se nejvýraznější rozdílné hodnocení týká preference hodnoty Spása duše, která je u věřících na prvním místě, u běžné populace na místě posledním.

Tabulka č. 2

Statisticky významné rozdíly v preferenci hodnot mezi zadanými a nezadanými

\begin{tabular}{lcccc}
\multirow{2}{*}{ Hodnoty } & \multicolumn{2}{c}{ Medián } & Z & p \\
\cline { 2 - 3 } & nezadaní & zadaní & & 0,040 \\
\hline Zralá láska & 3,0 & 2,5 & 2,059 & 0,005 \\
Krása & 12,0 & 14,0 & $-2,839$ & 0,350 \\
Rovnost & 10,0 & 11,0 & $-2,111$ & 0,011 \\
Spása duše & 1,0 & 1,0 & $-2,532$ & 0,028 \\
Společenské uznání & 12,0 & 13,0 & $-2,0196$ & 0,038 \\
Upř́mné př́telství & 3,0 & 5,0 & $-2,071$ & 0,004 \\
Moudrost & 4,0 & 6,0 & $-2,848$ & 0,033 \\
Fantazie & 12,0 & 13,0 & 2,127 & 0,048 \\
Nezávislost & 10,5 & 12,0 & 1,976 &
\end{tabular}

Souvislost náboženské praxe a vnímání vlastních, biblických a církevních názorů ohledně partnerských vztahů

Shoda v hodnocení vlastních, biblických a církevních názorů byla zkoumána prostřednictvím vybraných otázek dotazníku. Postoje respondentů k těmto položkám jsou zobrazeny v grafu č. 1. 


\section{Graf č. 1: Hodnocení položek týkající se biblických, církevních a subjektivních názorů}

Bible klade hodnotu "Boha" před hodnotu "Rodiny"

Církev klade hodnotu "Boha" před hodnotu "Rodiny"

Souhlasím s tím, aby byla hodnota "Boha" na prvním místě před hodnotou "Rodiny"

Podle Bible by měl každý křest’an usilovat o uzavření manželství a založení rodiny

Podle církve by měl každý křest'an usilovat o uzavření manželství a založení rodiny

Myslím si, že by každý křest’an měl usilovat o uzavření manželství a založení rodiny

Bible nepodporuje osamělý život jedince bez partnera

Církev nepodporuje osamělý život jedince bez partnera

Souhlasím s tím, aby církev nepodporovala osamělý život jedince bez partnera

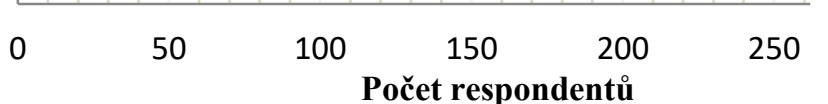

$$
\begin{aligned}
& \text { Zcela souhlasím } \quad \text { Spíše souhlasím } \quad \text { Neumím posoudit } \\
& \text { Spíše nesouhlasím } \square \text { Zcela nesouhlasím } \square \text { Neodpověděli }
\end{aligned}
$$

Z toho přehledu je patrné, že mladí křest'ané se více ztotožňují s biblickými názory než s církevními. Církevní stanoviska jsou podle hodnocení křest’anů více prorodinně orientována. Tento fakt souvisí také s pocit’ováním výraznější podpory a motivováním svobodných věřících k uzavírání manželství a zakládání rodin v církevním prostředí.

Objektivně přitom není pocit’ován tlak na nezadané, aby uzavírali manželství, nicméně byla prokázána souvislost mezi rodinným stavem a osobní zkušeností s pocit’ováním tohoto tlaku $\left(\chi^{2}(7)=18,25405 ; p<0,01\right)$. 
Respondenti upozorňující na tento tlak jej pocit’ovali (př́íp. stále pocit’ují) více ve svém sboru ${ }^{5}$ a společnosti věřících osob, než v církvi jako takové. Dále svobodní jedinci nejvíce pocitují tento druh tlaku ze strany své rodiny (viz graf č. 2.).

\section{Graf č. 2}

\section{Zdroje tlaku na uzavírání partnerských vztahů $(N=48)$}

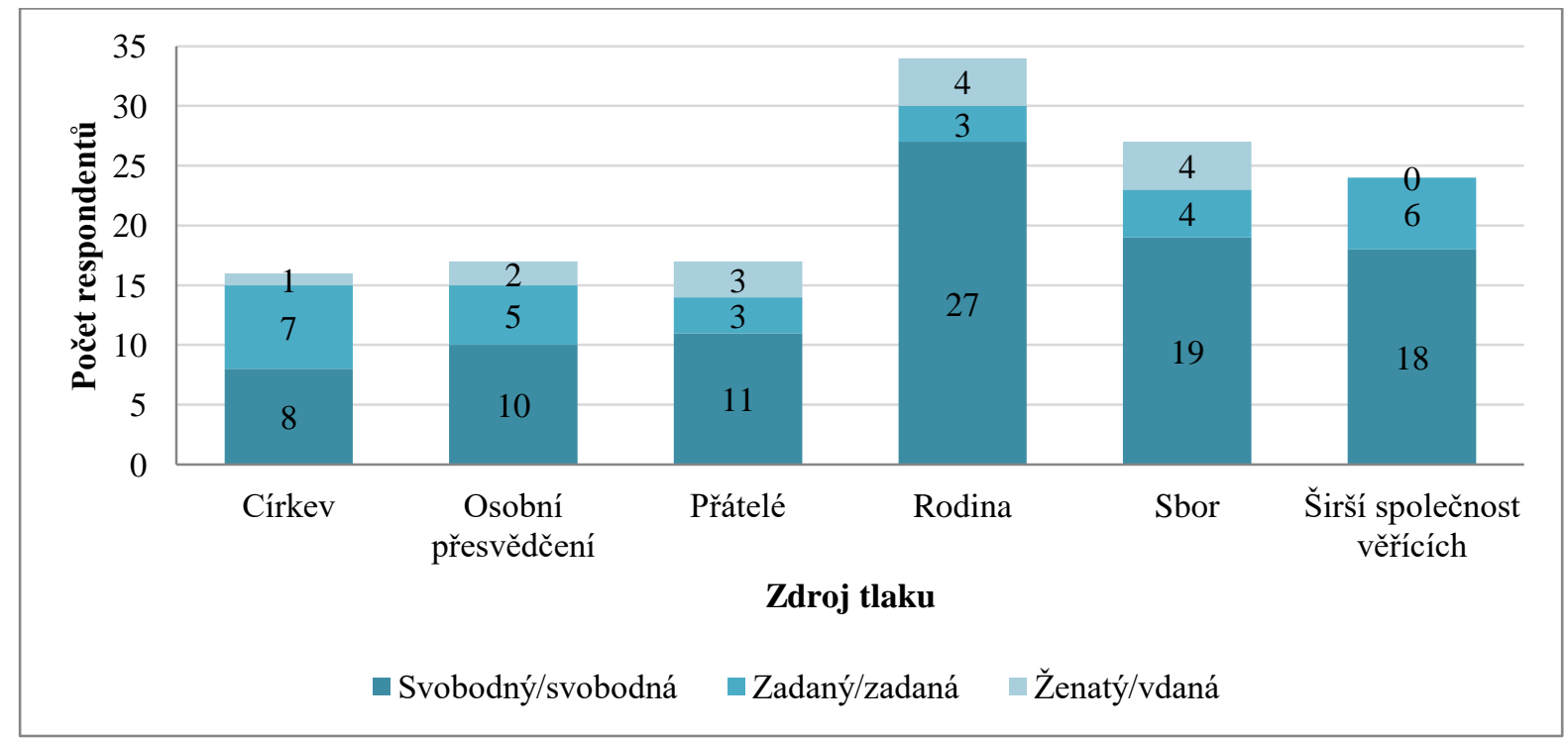

Pozn.: Průměrný počet identifikovaných zdrojů tlaku na osobu $=2,8$.

Z výstupů studie vyplývá, že míra náboženské praxe jedince souvisí s tím, nakolik jedinec vnímá shodu církevních názorů s biblickými koncepcemi, a nakolik s těmito stanovisky subjektivně souhlasí. Jednotlivé indikátory náboženské praxe a statistická hodnota souvislosti jsou uvedeny v tabulce č. 3, statisticky významné souvislosti jsou vyznačeny tučně. Míra individuální náboženské praxe nesouvisí podle Kruskal-Wallisovy analýzy s tím, jestli daný jedinec vyrůstá v úplné nebo neúplné rodině $(\mathrm{H}(2, \mathrm{~N}=262)=0,8510246, \mathrm{p}>0,05)$, nebo jestli je alespoň jeden z jeho rodičů věřící $(\mathrm{H}(2, \mathrm{~N}=252)=-0,01, \mathrm{p}>0,99)$.

\footnotetext{
${ }^{5}$ Pojem „sbor“ v textu označuje místní církevní společenství vztahující se na určité místo či oblast. Sbor (farní sbor) je pojem více používaný v protestanské terminologii, v katolické církvi se častěji používá pojem „,farnost“.
} 
Tabulka č. 3

Indikátory náboženské praxe a hodnota souvislosti (hodnota $\chi^{2}, p<0,001$ )

\begin{tabular}{lcc} 
Indikátor náboženské praxe & $\begin{array}{c}\text { Pocitování shody } \\
\text { církevních stanovisek s } \\
\text { biblickými }\end{array}$ & $\begin{array}{c}\text { Subjektivní souhlas } \\
\text { s církevními a biblickými } \\
\text { stanovisky }\end{array}$ \\
\hline Délka období chození do sboru & 5,045917 & 2,111646 \\
Frekvence docházení na bohoslužby & $\mathbf{6 6 5 , 7 1 0 7}$ & $\mathbf{7 3 1 , 1 7 7 9}$ \\
Frekvence docházení na setkání mladých věř́cích & 12,20993 & $\mathbf{1 7 , 2 4 2 8 2}$ \\
Četba Bible & $\mathbf{3 0 9 , 1 4 9 1}$ & $\mathbf{3 2 0 , 1 2 3 6}$ \\
Modlení se & $\mathbf{4 1 9 , 2 7 4 2}$ & $\mathbf{4 5 8 , 3 6 1 3}$ \\
Znovuzrození & $\mathbf{8 , 4 2 8 7 0 3}$ & 3,246734 \\
Velikost sboru & 5,213773 & 0,935210 \\
\hline
\end{tabular}

\section{Hodnocení prorodinné atmosféry ve vztahu s rodinným stavem jedince}

Hodnocení „prorodinné atmosféry“ $v$ církevním prostředí bylo rozděleno na posouzení tří oblastí: 1) pocitování tlaku v církvi/sboru na svobodné jedince, aby navazovali partnerské vztahy; 2) vnímání rozdílného přístupu a postavení k nezadaným a zadaným ve sboru; 3) míra spokojenosti s církevními a sborovými aktivitami a programy v oblasti partnerských vztahů, manželství a rodiny.

Hodnocení respondentů v otázce pocit’ování tlaku na svobodné jedince jsme popsali výše. Upřesňujeme, že rodinný stav nesouvisí s objektivním pocit’ováním tlaku $\left(\chi^{2}(7)=4,17\right.$; p > 0,05), pouze se subjektivním $\left(\chi^{2}(7)=18,3\right.$; p > 0,01). Nebylo tedy prokázáno, že by rodinný stav člena daného sboru měl vliv na to, jestli ve svém sboru obecně pocit'uje tlak na svobodné členy, aby uzavírali manželství. Bylo ovšem prokázáno, že rodinný stav člena sboru má souvislost s osobní zkušeností pocitováním tohoto tlaku na sebe sama. Podrobnější výklad je uveden v diskuzi.

Statistická analýza prokázala, že neexistuje rozdíl v pocit’ování rozdílného přístupu v církvi či sboru $\mathrm{k}$ nezadaným a zadaným jedincům podle rodinného stavu jedince $(\mathrm{H}(3, \mathrm{~N}=262)=2,987399 ; \mathrm{p}>0,05)$. Nicméně respondenti nezastávají v otázce pocit’ování rozdílného př́ístupu k nezadaným jedincům ve sboru jednotné stanovisko.

Zhruba $21 \%$ mladých věřících není spokojeno s publikacemi a aktivitami, které s tématem partnerských vztahů souvisí, a dále $22 \%$ věřících není spokojeno s programy zaměřenými na př́pravu do manželství. Byla prokázána souvislost mezi rodinným stavem jedince a mírou spokojenosti s programy, aktivitami a publikacemi církve $\mathrm{v}$ oblasti partnerských vztahů, manželství a rodiny $\left(\chi^{2}(11)=1293,24 ; \mathrm{p}<0,001\right)$. Obecně spokojenější jsou přitom svobodní jedinci (viz graf č. 3 ).

\footnotetext{
${ }^{6}$ Tzv. obrácení ve smyslu pozitivní reakce ,člověka na Boží pozvání k osobnímu obecenství a nabídku odpuštění: pokáni a vyznáni hřichu “(Novotný, 1935, 527).
} 


\section{Graf č. 3}

Míra spokojenosti respondentů podle rodinného stavu sprogramy a aktivitami církve $v$ oblasti partnerských vztahů, manželství a rodiny (v \%)

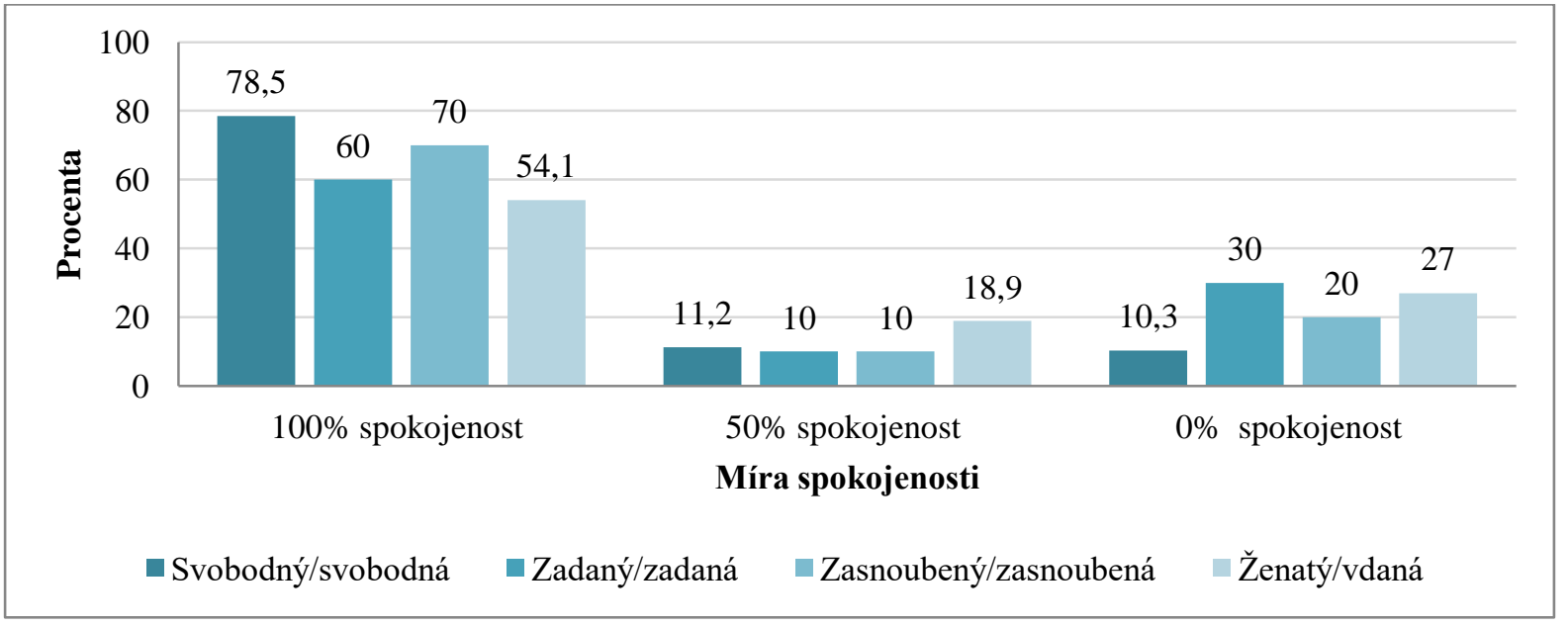

Téměř polovina respondentů vnímá, že církev výrazně zasahuje do toho, jak by měly partnerské vztahy vypadat $(46,6 \%)$, a že by se církev neměla primárně soustředit pouze na páry a manžele, ale také na svobodné jedince $(44,7 \%)$. Test dobré shody $\chi^{2}$ ani v jednom $\mathrm{z}$ těchto př́padi̊ nepotvrdil souvislost rodinného stavu $\mathrm{s}$ hodnocením těchto stanovisek $\left(\chi^{2}(23)=12,86558 ; \mathrm{p}>0,05 ; \chi^{2}(23)=13,70047 ; \mathrm{p}>0,05\right)$.

\section{Diskuze}

Vliv víry na hodnotový žebříček jedince vyplývá z výběru hodnot, které účastníci studie považují za nejdůležitější. Více než $3 / 4$ výzkumného souboru považuje hodnotu Boha za důležitější než hodnotu Rodiny, což odpovídá křest'anským koncepcím, podle kterých mají mít křest’ané na prvním místě Boha (viz Mt 6:33). Tento postoj potvrzuje i deklarované stanovisko nadpoloviční většiny účastníků, že křest’an není povinen usilovat o manželství a rodinu a že církev by měla podporovat svobodné jedince bez ohledu na to, jestli se rozhodnou vstoupit do manželství a založit rodinu či nikoliv. Dále se jedná o srovnání $\mathrm{s}$ českou běžnou populací prostřednictvím Rokeachovy škály hodnot, konkrétně v preferenci hodnoty Spása duše, kterou křest'ané vnímají jako nejvíce důležitou, zatímco běžná populace jako nejméně důležitou (Řehan, Cakirpaloglu, 2000). Přetrvávající primariát duchovního života nad osobním, potažmo rodinným životem, dosvědčuje také americká studie, kde protestantští studenti označili hodnotu Spása duše jako nejdůležitější, zatímco hodnotu Zralá láska na pozici čtvrté a hodnotu Rodinné bezpeči na pozici šesté (Shoemaker, Bolt, 1977).

Hodnota Spása duše stojí u zadaných i nezadaných věřících na prvním místě, v preferencích dalších hodnot se tyto skupiny mírně liší - hodnota Upř́mné přátelství je významnější pro nezadané, hodnota Zralá láska je významnější pro zadané. Statistickou významnost rozdílu v tomto hodnocení potvrdil i Mann-Whitneyho U test (viz tabulka č. 2). Lze tedy uvažovat, že rodinný stav jedince ovlivňuje preferenci hodnot týkajících se partnerských a rodinných vztahů. Výsledky poukazují na menší důležitost hodnot s tímto spojených 
u nezadaných jedinců, což je v souladu s výsledky výzkumu veřejného mínění (Červenka, 2004), podle kterého svobodní a bezdětní jedinci nepovažují hodnotu Rodiny za prioritu. $\mathrm{V}$ oblasti instrumentálních hodnot byl zaznamenán rozdíl u hodnoty Moudrost, kterou nezadaní jedinci hodnotili jako důležitější než zadaní jedinci, což může souviset s faktem, že 77 \% svobodných respondentů studuje.

Podle mladých věrících církev nepřistupuje k partnerským otázkám shodně s biblickými koncepcemi. Jak lze vidět na grafu č. 1, mladí křest’ané se více ztotožňují s biblickými stanovisky a církevní postoje vnímají jako nejednoznačné. Výsledky poukazují také na to, že církev přikládá hodnotě Rodiny větší význam než Bible nebo věřící jedinec. Oba tyto subjekty totiž podle výstupů studie nepovažují za nejdůležitější úkol církev podporovat a motivovat jedince $\mathrm{k}$ uzavření manželství a založení rodiny. $\mathrm{Z}$ tohoto důvodu je zřejmé, proč se křest’ané více kloní $\mathrm{k}$ biblickým stanoviskům, u kterých nepocit’ují tak silný prorodinný př́stup.

Jednotlivé faktory náboženské praxe mají vliv na pocitování míry shody mezi církevními a biblickými názory. Účast na bohoslužbách a četba Bible umožňují porovnání církevních koncepcí prezentovaných na shromážděních se stanovisky uvedenými v Bibli. Modlitba a znovuzrození se souvisí s osobním vztahem k Bohu budovaným zejména v soukromí.

Mezi mírou shody vlastních názorů s biblickými a církevními v souvislosti s náboženskou praxí jedince byla zjištěna negativní korelace, z čehož vyplývá, že čím více je jedinec nábožensky aktivní (čím vyšší vykazuje hodnotu indexu náboženské praxe), tím více ve svých názorech souhlasí $\mathrm{s}$ biblickými a církevními stanovisky (tím je menší rozdíl $\mathrm{v}$ hodnocení jednotlivých otázek vyjadřující vlastní, biblické a církevní stanovisko).

Výsledky studie poukazují na to, že objektivně není v církevním prostředí pocitován tlak na svobodné jedince, aby navazovali partnerské vztahy. Takový tlak vychází zejména $\mathrm{z}$ rodiny daného jedince, př́ípadně pak z konkrétního sboru nebo společnosti věřících osob, do které jedinec pocit'ující tlak na svobodné náleží. Tyto výsledky potvrzují také další zahraniční studie (Jackson, 2011).

Jednotlivé sbory zřejmě přistupují k nezadaným jedincům rozdílně, na což poukazuje rozdílné vnímání jedinců v otázce prístupu k nezadaným. Více než polovina účastníků studie si ovšem nemyslí, že by svobodní jedinci byli považováni za neschopné navazovat partnerské vztahy, nebo že by svobodný stav člena sboru ovlivňoval jeho hodnotu a postavení. Obdobný názor lze sledovat v celé české společnosti (Čadová, 2014) i zahraniční populaci (Goering, Krause, 2001). Navíc rodinný stav daného člena sboru nemá na pocit’ování tohoto př́istupu vliv. Tyto výsledky vyplývají také z jiných studií (Olatundum, 2013). Lze tedy uvést, že ve sborovém prostředí převládá rovnostranný prŕstup ke všem jedincům bez ohledu na jejich rodinný stav.

$\mathrm{Na}$ grafu č. 3 lze vidět, že s církevními a sborovými programy, akcemi a publikacemi zaměřenými na partnerské vztahy jsou nejvíce spokojeni nezadaní jedinci a nejméně spokojeni zadaní jedinci a jedinci žijící $\mathbf{v}$ manželství. Tento výstup může souviset $\mathrm{s}$ konkrétními oblastmi v rámci partnerských vztahů, na které se církev zaměřuje.

Jednou z těchto oblastí mohou být zásahy církve do partnerských vztahů, které více než polovina respondentů, bez rozdílu mezi zadanými a nezadanými, považuje za výrazné. Jedná se například o církevní zásady a doporučení, které nastavují v partnerských vztazích hranice, které $\mathrm{v}$ př́padě jejich překročení mohou $\mathrm{u}$ jedince vyvolat negativní emoce, což bylo 
potvrzeno studií realizovanou v Baptistické církvi, kde $80 \%$ jedinců, kteří porušili předmanželskou čistotu, mělo výčitky svědomí (Rosenbaum, Weathersbee, 2013). Celkové zaměření církve na partnerské vztahy potvrzuje i fakt, že téměř polovina respondenti̊ $(45,2 \%)$, bez souvislosti s jejich rodinným stavem, si nemyslí, že by se práce církve a sboru měla zaměřit především na páry a manžele, než na svobodné. Prorodinnou církevní orientaci potvrzují i zahraniční studie (Goering, Krause, 2001).

Z těchto výstupů lze tedy usuzovat, že nadměrná církevní regulace partnerských vztahů může být kořenem nespokojenosti zadaných a sezdaných jedinců. Vliv církevních intervencí v oblasti partnerských vztahů na vnímání a prožívání jedince ve sboru potvrzují také další studie (Pedersen, 2014; Eriksson, et al., 2013). Práce církve s páry ovšem nemusí mít pouze negativní efekt, jak potvrzují výstupy americké studie (Stenley et al., 2006), kde je práce církve s páry považována za prŕnosnou pro zvyšování spokojenosti a pevnosti manželství.

\section{Závěr}

Prvotní zmapování hodnocení prorodinné atmosféry $\mathrm{v}$ církvi otevírá prostor pro další výzkumné záměry a cíle. Zajímavou oblastí je diskrepance biblických a církevních názorů, kterou členové církve pocit’ují, a kde je možné získat bližší informace o konkrétních rozdílech $\mathrm{v}$ těchto stanoviscích. Účelné by bylo také zmapovat problematiku postavení nezadaných a zadaných osob ve sboru a konkrétnější formu pocit'ovaného tlaku na svobodné jedince.

V této oblasti se lze cíleně, vzhledem k výsledkům, zaměřit na práci církve s tlakem do manželství vycházejícího z rodinného prostředí. Na základě zjištěných výsledků je možné zavést vhodné intervence $\mathrm{v}$ další práci církve či sboru $\mathrm{v}$ těchto oblastech. V neposlední řadě se jedná o podrobnější prozkoumání církevních a sborových programů a aktivit $\mathrm{v}$ oblasti partnerských vztahů a konkrétních doporučení na další práci ze stran členů církve. Veškeré výstupy mohou být prakticky využity v církevní společnosti a přispět ke zvýšení obecné spokojenosti členů jednotlivých církví.

Oblast partnerských vztahů je bohatá na podněty k výzkumům, které vyplývají z výstupů jak této práce, tak mnoha dalších a také reflexe nedostatků a limitů studie. V prvé řadě se jedná o formu sběru dat, protože vyvěšení dotazníku na internetu neumožňuje kontrolu správného a úplného vyplnění. Rovněž jednotlivé otázky a položky v dotazníku narážejí na riziko odlišného subjektivního pochopení a reakce účastníků, což je přirozený nedostatek dotazníkové metody.

Limity se týkají také výzkumného vzorku. Studie probíhala primárně mezi členy Římskokatolické církve a Slezské církve evangelické a.v. Zapojeni byli i příslušníci jiných církví, nicméně jejich zastoupení ve výzkumném vzorku nebylo výrazné. Stejně tak nebyli rovnoměrně zastoupeni muži a ženy $(29,4$ \% mužů ku 70,6 \% žen) a jedinci podle rodinného stavu, což byla jedna z hlavních nezávislých proměnných pro analýzu dat. Nejednalo se o reprezentativní soubor, proto není možné výsledky studie zobecňovat na celou populaci křest’anů v České republice. Je nutné také zohlednit nejednotnost církví v otázkách manželství, sexuality a rodičovství, která se může odrážet v přistupu a pojetí vnímání prorodinné atmosféry v církvi mezi mladými věřícími. 
Předností této studie je prvotní mapování hodnocení prorodinných otázek v církvi mladými křest’any v českém prostředí. Vzhledem k tomu, že otázka rodiny a partnerských vztahů je $\mathrm{v}$ církevní sféře stále aktuální, je účelné sledovat přístup $\mathrm{k}$ této problematice $\mathrm{v}$ souvislosti se společenskými změnami a všeobecným hodnotovým nastavením společnosti. Církev by měla reflektovat potřeby svých členů i širší veřejnosti v těchto tématech a adekvátně uzpůsobovat své programy a aktivity.

\section{Seznam literatury}

Adventisté sedmého dne věř́i. Výklad 27 základních věroučných článki̊. (1999). Praha: Advent-Orion.

Český ekumenický překlad. Písmo svaté Starého a Nového zákona. (2001). Praha: Česká biblická společnost.

Čadová, N. (2014). Postoje českých občanů k manželství a rodině - prosinec 2013. Centrum pro výzkum veřejného mínění. http://cvvm.soc.cas.cz/media/com_form2content/documents/c1/a7165/f3/ov140120.pdf

Červenka, J. (2004). Hodnotové orientace v naší společnosti. Centrum pro výzkum veřejného mínění.

http://cvvm.soc.cas.cz/media/com form2content/documents/c3/a3942/f11/100044s_cervenka-hodnoty.pdf

Česká biskupská konference. (2001). Příprava na svátost manželství. Praha: Sekretariát české biskupské konference.

Dolista, J. (1994). Naděje vložená do manželství (Teologicko-pastorální studie). Olomouc: Matice cyrilometodějská.

Emanovský, P. (2013). Úvod do metodologie pedagogického výzkumu. Olomouc: Univerzita Palackého v Olomouci.

Eriksson, E., Lindmark, G., Axemo, P., Haddad, B., \& Ahlberg, B. M. (2013). Faith, Premarital Sex and Relationships: Are Church Messages in Accordance with the Perceived Realities of the Youth? A Qualitative Study in KwaZulu-Natal, South Africa. Journal of Religious Health, 52(2), 454-466.

Fialová, L. (2006). Trendy ve sňatkovém chování obyvatelstva České republiky ve 20. století. Demografie, 48 (2), 97-108.

Goering, E. M., \& Krause, A. (2001). Odd Wo/man Out: The Systematic Marginalization of Mennonite Singles by the Church's Focus on Family. Mennonite Quarterly Review, 75(2), 221-230. 
Jackson, I. (2011). Social pressure, marital expectancy, and family formation values in the pursuit of marriage: A study of psychological distress in Modern Orthodox Jewis women. Dissertation. Chicago: Rooswelt University.

Jan Pavel II. (1996). Familiaris Consortio: O úkolech křestanské rodiny v současném světě. Praha: Zvon.

Katechismus katolické církve. (1995). Praha: Zvon.

Kotasová, H. (2015). Hodnocení prorodinné atmosféry mezi mladými věřícími. Nepublikovaná diplomová práce. Olomouc: Univerzita Palackého v Olomouci.

Novotný, A. (1935). Biblický slovnik. Praha: Kalich.

Olatundum, O. A. (2013). A Socio-religious perspective of late marriage and stigmatization of single adults and its impact on the Church in Nigeria. Review of European Studies, 5(4), 165171.

Pedersen, W. (2014). Forbidden Fruit? A Longitudinal Study of Christianity, Sex, and Marriage. Journal of Sex Research, 51(5), 542-550.

Rosenbaum, J. E., Weathersbee, B. (2013). True Love Waits: Do Southern Baptists? Premarital Sexual Behavior Among Newly Married Southern Baptist Sunday School Students. Journal of Religious Health, 52, 263-275.

Řehan, V., Cakirpaloglu, P. (2000). Sociální status a hodnotová orientace mladé generace. Československá psychologie, 44(3), 202-215.

Shoemaker, A. Bolt, M. (1977). The Rokeach Value Survey and perceived Christian values. Journal of Psychology and Theology, 5(2), 139-142.

Stenley, S. M. (2006). Premarital education, marital quality, and marital stability: Findings from a large, random household survey. Journal of Family Psychology, 20(1), 117-126.

Suchá, E. et al. (eds). (2006). Kniha svornosti: symbolické čili vyznavačské spisy evangelických cirkví augsburské konfese: nové české znění podle standardní německo-latinské edice, s prihlédnutím $k$ dosavadním převodìm. Praha: Kalich.

Šejda, J., Šmerhovský, Z., Göpfertová, D., et al. (2005). Výkladový slovník epidemiologické terminologie. Praha: Grada Publishing.

Zásady Slezské cirkve evangelické a. v. (2004). http://www.sceav.cz/cs/dokumenty-amateriály 


\section{Údaje o autorech:}

Mgr. Bc. Hana Wisełková je absolventkou jednooborové psychologie (2015) a oboru Pedagogika-Sociální práce (2016), obojí na Univerzitě Palackého v Olomouci. Pracuje jako psycholožka a sociální pracovnice v organizaci Slezská diakonie, kde se zaměřuje zejména na práci s lidmi závislými na návykových látkách a s obět’mi domácího násilí či osobami s problémy v mezilidských vztazích a rodinnými problémy. Od roku je 2016 účastnicí výcvikového programu v Gestalt psychoterapii organizovaný institutem Dialog.

\section{Kontaktní údaje:}

Adresa: Poradna ELPIS Třinec, Slezská diakonie, Máchova 643, 73961 Třrinec E-mail: wiselkovahana@gmail.com

PhDr. Marek Kolařík, Ph.D., působí jako odborný asistent na Katedře psychologie FF UP v Olomouci. Absolvoval, mimo jiné, výcvik v rodinné a systemické terapii, aktivně (spolu)pracuje s klienty i výcvikovými skupinami. Od roku 2012 je členem prezídia Asociace manželských a rodinných poradců ČR.

\section{Kontaktní údaje:}

Adresa: Katedra psychologie FF UP v Olomouci, Vodární 6, 77100 Olomouc E-mail: marek.kolarik@upol.cz

Wisełková, H., \& Kolařík, M. (2018). Hodnocení prorodinné atmosféry mezi mladými věřícími. E-psychologie, 12(1), 1-14. Dostupné z http://e-psycholog.eu/pdf/wiselkova-kolarik.pdf doi: 